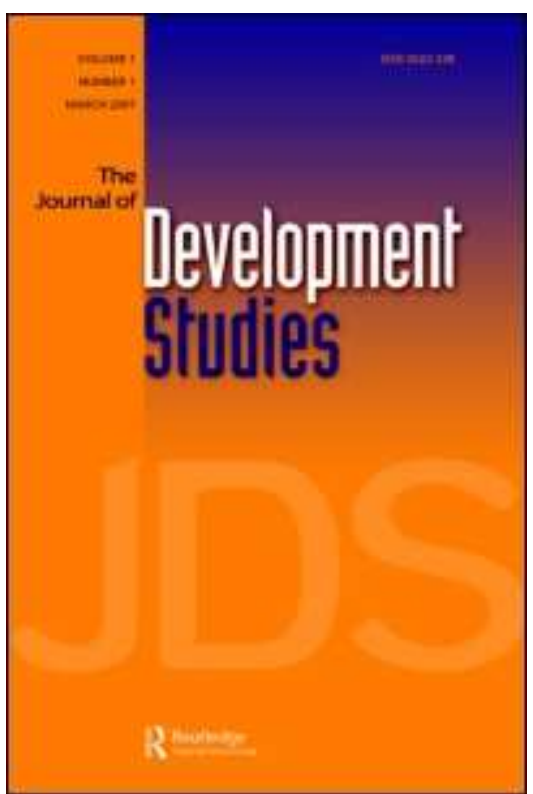

\title{
Failing to Yield? Ploughs, conservation agriculture and the problem of agricultural intensification. An example from the Zambezi Valley, Zimbabwe
}

\begin{tabular}{|r|l|}
\hline Journal: & Journal of Development Studies \\
\hline Manuscript ID: & FJDS-2010-Nov-0060.R2 \\
\hline Manuscript Type: & Original Manuscripts \\
\hline Keywords: & $\begin{array}{l}\text { Policy }<\text { Government, State Policy, \& Ideologies, Livelihoods }< \\
\text { Economics, Agriculture }<\text { Environmental issues, Environment }< \\
\text { Environmental issues, Africa }<\text { Geographical Area }\end{array}$ \\
\hline
\end{tabular}

\section{SCHOLARONE" Manuscripts}




\begin{abstract}
Agricultural intensification, or increasing yield, has been a persistent theme in policy interventions in African smallholder agriculture. This article focuses on two hegemonic policy models of such intensification: (1) the 'Alvord model' of ploughbased, integrated crop-livestock farming promoted in colonial Zimbabwe, and; (2) minimum-tillage mulch-based, Conservation Agriculture (CA), as currently preached by a wide range of international agricultural research and development agencies. An analysis of smallholder farming practices in Zimbabwe's Zambezi Valley, reveals the limited inherent understanding of farmer practices in these models. It shows why many smallholder farmers in southern Africa are predisposed towards extensification rather than intensification, and suggests that widespread CA adoption is unlikely.
\end{abstract}

\title{
1. Introduction
}

'The Gospel of the Plow means working together with God, in order to get good crop yields while at the same time we take good care of the soil (...) In order to bring this about, a spirit of reverence for the soils must be created, which is... a sort of religion (...) The heathen African dug his land while standing trees, skeletons, stumps and fallen trees were scattered all about. ...he planted the seed and trusted to the witchdoctors, rainmakers, ancestral spirits and demons to do the rest. (...) if those people could only be taught the Gospel of the Plow...' (Emery Alvord, Agriculturalist for Natives in Southern Rhodesia from 1926 to 1950$)^{1}$

'Conservation Agriculture $[\mathrm{CA}] \ldots$ can be difficult for many people to accept because it goes against many of their cherished beliefs. How can crops be grown without plowing the land? Overcoming this 
mindset of the need for plowing is a major step in achieving successful CA systems.' (Zimbabwe CA Taskforce, 2008:5) $)^{2}$

\begin{abstract}
'God has revealed a very simple conservation farming method with an implementation management teaching, which when applied, helps people to apply the Gospel to their lives.' (Foundations for Farming, formerly Farming God's Way website, 2010) ${ }^{3}$
\end{abstract}

The above quotes signal two persistent themes in the history of agricultural intervention in the smallholder sector in southern Africa. First, the perception that smallholder farmers' practices are backward, destructive, and in need of revelation. Second, the religious zeal by which (colonial) interventionists have sought to persuade African farmers to adopt more intensive agricultural practices, that is, to increase yield (harvest per surface area). This is most evident in Zimbabwe where an agricultural intensification package was promoted as early as the 1920s. Emery Alvord, an American missionary, turned the plough into a symbol of modern agriculture while promoting a package of integrated crop-livestock farming. It became the hegemonic model for African farming underpinning a wide range of policy interventions in African agriculture in colonial Zimbabwe (Wolmer and Scoones, 2000; Bolding, 2004). Such interventions initially took the form of 'demonstrations' to African farmers, but religious zeal increasingly made way for compulsion.

Contemporary attempts at agricultural intensification in African agriculture continue to be informed by conservationist concerns. Yet, in contrast to the plough-based Alvord model, current interventions are based on minimum-tillage and retention of a mulch of crop residues, through a technical package referred to as 'Conservation Agriculture" ${ }^{4}, \mathrm{CA}$. A powerful lobby of international donors, development and agricultural research agencies crusades to extend what has become the current hegemonic policy model for agricultural intensification. Collaborating in a taskforce, NGOs and donors promoting CA have garnered considerable 
financial and political support in Zimbabwe ${ }^{5}$. The model has even been included in the National Agricultural Policy of Zambia (MACO, 2004), and recognised by Zimbabwe's president as a means to "make savings on draught power requirements and minimise land degradation, ${ }^{\text {. }}$

This article analyses these two hegemonic policy models for agricultural intensification from a comparative perspective. Highlighting some striking similarities in extension approach, notably the invocation of God and the use of science-based demonstration plots, the main focus is on the ideas and inherent assumptions about smallholder farming systems underpinning both models. It is suggested that protagonists of CA have learned little from the earlier, colonial attempts to intensify smallholder agriculture as spearheaded by Alvord. While resource conservation and sustainable production have remained persistent concerns guiding interventions in smallholder agriculture, so remains the disregard for the socio-economic circumstances and the rationale of African smallholder practices ${ }^{7}$. Like in Alvord's days, interventions take a 'one size fits all' form that ignores the diversity of existing farming practices. Farming Systems Research (FSR) and subsequent participatory approaches epitomised by the 'Farmer First' approach (Chambers et al., 1985) - appear to have had no bearing on the development and extension of CA to smallholder farmers in Africa. Rather than questioning the agronomic merits of the technologies promoted, this article is therefore concerned with the suitability of CA technologies to the socio-economic realities of smallholder farming systems in southern Africa.

Malnutrition and population growth (2.3\% per annum) underline the need for increased agricultural production in sub-Saharan Africa. As the most suitable areas for agriculture are already cultivated, agricultural intensification seems a logical strategy (World Bank, 2008). Yields in smallholder farming systems of southern Africa remain appallingly low despite technological innovations such as improved seeds and fertilisers. Average cereal yields in 
smallholder agriculture have stagnated in Africa since the 1960s, whilst they have nearly doubled in the rest of the world (Huang et al., 2002). Large-scale commercial farming on the African continent also performs considerably better than the smallholder sector. For instance, in Zimbabwe in the period 1970-2000, maize yield averaged $0.8 \mathrm{t} \mathrm{ha}^{-1}$ (std. dev. $0.4 \mathrm{tha}^{-1}$ ) for the smallholder sector and $3.9 \mathrm{t} \mathrm{ha}^{-1}$ (std. dev. $1.0 \mathrm{t} \mathrm{ha}^{-1}$ ) for the commercial farming sector (Andersson, 2007). Differences in agricultural potential go a long way in explaining this disparity, as the best agricultural lands were expropriated for white settlers during the colonial era. However, even in similar agro-ecological circumstances, huge differences in yields are observed between the majority of smallholder farmers and the best performing ones (Zingore et al., 2007), suggesting that while a potential for higher land productivity exists, it is not realised because of social and economic factors (Djurfeldt et al., 2008). By inferring from an analysis of the labour, cash and price constraints, as well as risk mitigation strategies of smallholder farmers in northern Zimbabwe, it is shown why many smallholder farmers in southern Africa do not - or are not able to - intensify their production, but instead, are disposed towards agricultural extensification. Appreciating the rationale of existing farming practices of smallholder farmers, it is suggested that many farm practices promoted under the banner of CA are likely to befall a similar fate as Alvord's recommendations for agricultural intensification.

This article is divided in two parts. Part I compares the Alvord model and CA, looking at the ideas and assumptions underpinning the technologies promoted, the extension approaches deployed, and the fate of the Alvord model some 80 years after it was introduced. Part II shifts the attention to smallholder farming practices and their embedding in a wider socioeconomic environment. It builds on extensive fieldwork in Dande Communal Area in the Zambezi Valley, a sparsely-populated agricultural frontier in northern Zimbabwe, 


\section{PART I: MODELS OF AGRICULTURAL INTENSIFICATION}

\section{Theoretical models of agricultural production growth}

Two ideal-typical models to increase agricultural production may be distinguished. First, increased farm output may be achieved through 'extensification'; extending the area under cultivation, while maintaining or reducing inputs per unit area (Figure 1a). Yields remain stable or decrease whilst water and nutrient losses per unit area often remain unaltered (Erenstein, 2006). Second, production increases may be achieved by means of intensification. Yield is increased through greater capital and/or labour input per unit area. The 'Green Revolution', which drove massive production increases in Asia (World Bank, 2008), is a typical example of capital-driven intensification (that is use of hybrid seeds, chemical inputs and mechanization; Figure 1b). 'Ecological intensification' increases resource use efficiency for example light, water and nutrient use (Figure 1c; Giller et al., 2002; 2006). It revolves around the idea of sustainable production, seeking to increase land productivity while conserving natural resources, that is soil, water, and surrounding wild nature. However, ecological intensification often requires more labour per unit area.

Figure 1 
Farming technologies are often classified as either land-saving or labour-saving, that is, as resulting in agricultural intensification and extensification respectively (Erenstein, 2006). In practice, however, technologies may be used differently, rendering a clear-cut classification problematic. Intensification and extensification are seldom mutually exclusive. For instance, whereas chemical fertilisers are generally seen as a land-saving technology, their massive adoption by Zimbabwean smallholder maize growers in the mid 1980s went hand in hand with an expansion of land cropped with maize (Andersson, 2007).

Besides farming technologies, socio-economic circumstances may also direct farm development toward intensification or extensification. First, whilst agricultural intensification is often triggered by land scarcity, extensification is a common strategy when sufficient land is available (Boserup, 1965; Erenstein, 2006). Second, proximity to urban markets increases the incentives for intensification, reducing costs for input procurement and marketing (Woodhouse, 2002; Erenstein, 2006). Similarly, unfavourable market access in remote areas may hamper intensification (Woodhouse, 2002; Bamire and Manyong, 2003).

Below we discuss the Alvord and CA models for the intensification of African smallholder agriculture. Although developed in different historical contexts and based on different technologies - most notably, opposing views regarding use of the plough - the paragraphs below reveal a striking historical continuity in their disregard for the rationale of existing farm practices, and in their extension approach.

\section{Segregation, modernization and erosion control: the 'Alvord model' of agricultural intensification}

Emery Alvord's appointment as "Agriculturalist for the Instruction of Natives" in 1926 was the result of a proposal for the industrial development of Africans, formulated by the Chief 
Native Commissioner, Mr. Keigwin (Bolding, 2003:37). Agricultural intensification in the lands set aside for African occupation - the Native Reserves (now called Communal Areas) was Alvord's key task. He was to,

... develop Native Reserves so as to enable them to carry a larger population, and so avoid, as far as possible, the necessity for acquisition of more land for native occupation.' (Chief Native Commissioner, Annual Report 1932)

Alvord's efforts were thus part and parcel of the colonial governments' racial segregation policies. Concentrating more people in the Native Reserves meant that permanent cultivation had to replace the common practice of shifting cultivation. While working as a missionary at Mount Selinda on the country's eastern border, Alvord developed a set of agricultural practices that could increase yields and modernise African agriculture (Page and Page, 1991; Davis, 1992). Laid down as 'commandments' for permanent agriculture (Bolding, 2004: 53), the 'Alvord model' of modern agriculture became an integral part of the civilizing enterprise colonial officials and missionaries such as Keigwin and Alvord had set themselves. Emblematically represented by the plough, a set of blanket recommendations consisting of five key practices - ploughing, manuring, crop rotation, sole cropping ${ }^{8}$ and planting in lines sought to sustain the permanent cultivation of the generally poor soils of the Native Reserves (Table 1a, Page and Page, 1991; Davis, 1992). In agronomic terms, this farming model aimed to increase both input supply to the crop (for example manure application) and resource use efficiency through improved crop management (for example planting in lines).

Table 1 


\section{From 'demonstration' to compulsion}

Underpinned by an ideology of racial segregation and paternalistic development, Alvord's package for 'modern agriculture' was promoted in a number of ways. At agricultural training centres in Domboshawa, north of Harare, and in Tsholotsho, in the south, mission-educated Africans were trained to become 'agricultural demonstrators' (extension workers). They were placed in the Native Reserves to demonstrate the standardised set of modern husbandry practices in the fields of those willing to adopt 'modern agriculture'. Alvord emphasised that demonstrators were to work the plots together with the plot owners, building on 'learning by doing' and 'seeing is believing' (Bolding, 2003: 44, 46). A second policy was the Master Farmer programme, a training programme for farmers that has survived well into the postcolonial era (see Bolding, 2004).

As Alvord rolled out his demonstration and Master Farmer programmes, land degradation in the Native Reserves seemed only to worsen in the eyes of colonial government officials, including Alvord himself. Fuelled by a visit to the USA during the Great Dust Bowl in 1935, colonial interventions in African smallholder agriculture became increasingly informed by conservationist concerns (McGregor, 1995; Wolmer and Scoones, 2000). Although blamed on African smallholders' misuse of the land, land degradation in the Reserves was partly of the colonial governments' own making. More and more people were pushed onto these degradation-prone lands (Andersson, 2007: 683). In addition, the alarming rates of soil erosion were often based on landscape-level aggregations of plot-level estimates, thus ignoring the complex patterns of deposition across landscapes (Campbell et al., 1997) ${ }^{9}$.

However ill-informed, erosion rates were used to justify more stringent soil conservation policies such as the Natural Resources Act of 1941, which empowered Native Commissioners to issue orders on - 'Alvordian' - farming methods to be used, and compel African farmers to 
Alvord's gospel, technology adoption and the plough

Demonstrated and enforced, Alvord's standardised model for 'modern farming' has left its legacy. Zimbabwean smallholders have adopted and adapted some or all five key practices ploughing, manuring, crop rotation, sole cropping and planting in lines - despite criticism on their agronomic merits, applicability, and sustainability (for an overview, see Bolding, 2003). For instance, already during his time in office (1926-1950), Alvord had to acknowledge that his manure recommendations to maintain soil fertility in permanently cultivated lands were ill-suited. Most smallholder farmers simply did not have enough cattle (12-16 head per arable hectare) needed to supply the required rate of manure (Bolding, 2003: 51). ${ }^{10}$ In 1965, it was estimated that less than half of the Native Reserve farmers owned any cattle at all (Machingaidze, 1991). Alvord's crop rotations were equally unsuited to the conditions of smallholder farmers as they did not take into account the different labour requirements, dietary needs and preferences or marketability of different crops (see below). Ploughing, solecropping and planting in lines have, however, become widely practised and regarded as proper farming practice by smallholder farmers. But did these 'Alvordian' technologies result in agricultural intensification? These three components of the package do have land-saving properties - that is that may lead to intensification - but they also have labour-saving properties - that is that may lead to extensification (Table 1a). In many areas where 
population was sparse, they enabled farmers to manage larger lands, and if close to markets, this gave rise to a category of so called 'plough entrepreneurs', who opened up extensive land areas to increase production (Ranger 1985: 36; Phimister 1988: 72-79,143). Colonial administrators noted:

\footnotetext{
'...the native is rapidly taking to the plough and the use of the plough is becoming almost general throughout the country... the average yield in bags per acre is deplorably low and has decreased with the advent of the plough.' ${ }^{11}$
}

In those areas where population had become dense - as a result of the colonial state's segregationist land policies - such an extensification-based development path was less feasible. It was in these areas that Alvord's demonstrators 'tended to secure the greatest degree of cooperation from cultivators' (Phimister 1988: 275), adopting labour demanding components such as manuring. But even in these densely populated areas, demonstrators were generally welcomed by only a few farmers, most notably the entrepreneurial ones, as they reduced their labour burden. In some cases demonstrators even assumed the role of farm managers for entrepreneurial farmers (Ranger 1985:62; Phimister 1988:143-145). The adoption of the plough for agricultural extensification thus has to be understood in the context of smallholder's production constraints and market opportunities. Both were at least partially structured by colonial land and marketing policies.

It is perhaps somewhat ironic that in his autobiography, 'The Gospel of the Plow', Alvord took the plough as the symbol of his life-time efforts to intensify African land use. In 1926, when Alvord was appointed, it was estimated there were already over 27,000 ploughs in use in the Native Reserves. In the following five years this number almost doubled to over 53,000 , when a mere 37 demonstrators were working in the Native Reserves (Government of 
Southern Rhodesia, 1952). Alvord and his demonstrators were thus not responsible for the rapid uptake of the plough by African farmers. Alvord referred to the rise of the plough as a mixed blessing, lamenting its 'misguided' use; extensive ploughing could increase soil erosion and farmers who opened up large tracks of land with the plough, could often not manage the additional hand-weeding (Bolding, 2003: 55-56). Nevertheless, the success of African smallholders' extensive market production of maize brought them in direct competition with white settler farmers. The latter turned against colonial officials like Alvord for stimulating Africans to produce. The settler state yielded to pressures of the white farmers, and introduced discriminatory marketing legislation such as the Maize Control Act (1931), which reduced market prices for African producers. Such state intervention in markets did not always cause reduced market production: 'The percentage of African sales to total African production and to total sales increased significantly' in the 1930s, as farmers tried to sustain their income by producing more (Phimister 1988:186). State-induced falling market prices could thus contribute to agricultural extensification as farmers tried to reduce costs. For Alvord, however, it was the lack of grain markets for African producers that was to blame for the failure of intensification (Stocking, 1978; Page and Page, 1991; Davis, 1992).

Rather than Alvord's recommendations and extension programmes, the growing population concentrated in the Native Reserves that eventually forced smallholder farmers to cultivate the same land permanently. Alvord's recommendation to use manure followed as an - insufficient - response to declining yields, as did the use of mineral fertilisers. Having had no regard for the production constraints of smallholder farming systems, it can be concluded that in his time (1926-1950), Alvord's package for agricultural intensification was largely a failure, as it was diverted for extensification. Yet the legacy of his 'Gospel of the Plough' is immense, as the next sections will reveal. 


\title{
4. From plough adoption to abandonment: what has changed?
}

\author{
Stemming land degradation through Conservation Agriculture
}

Conservationist concerns continue to inform agricultural intervention in the post-colonial period. Now framed in terms of an eroding natural resource base and biodiversity loss, underpinning contemporary policies is the persistent idea that African farming practices are both unproductive and destructive. Not surprisingly, Zimbabwe has been fertile ground for the introduction of Conservation Agriculture (CA). Based on the simultaneous application of three principles - minimal soil disturbance, permanent soil cover, and crop rotations (www.fao.org/ag/ca; Table 1b) - this model of ecological intensification (Figure 1c) has recently gained momentum in southern Africa following its successful adoption on large-scale mechanised farms in South America, North America and Australia (Kassam et al., 2009). In the latter, CA depended on use of labour-saving herbicides (unlike the hand-hoe basin-based packages promoted to Zimbabwean smallholders). It may be seen as a new gospel, this time to abandon the plough (see www.foundationsforfarming.org).

The CA principles of minimum soil disturbance, achieved through minimum-tillage, and permanent soil cover through retention of a mulch of crop residues are interdependent practices (as tillage would bury the mulch). Other components of the technological package can be viewed as consequences (Figure 2). For example, crop rotation becomes necessary as crop residues retained on the soil as mulch may carry pests and diseases.

Recent projects and training manuals promoting CA evidence a tendency to include more and more technological components. For instance, the Foundations for Farming ${ }^{12}$ promotes composting as part of the CA package, ICRISAT includes fertiliser micro-dosing (Twomlow et al., 2008a), while ICRAF promotes 'Conservation Agriculture with trees ${ }^{\text {'13 }}$. Although such 
Figure 2

Conversion justified with science... and extended with faith

The similarities between the Alvord and CA models for agricultural intensification extend beyond a shared ideology of resource conservation and land degrading farm practices of African smallholders. First, protagonists of CA deploy similar extension strategies. For instance, in manuals, documentaries and slide-shows ${ }^{14}$, the land degrading and inefficient nature of African smallholder agriculture is often illustrated by pictures of gully erosion and farmers in fields with stunted, yellowish crops. The superiority of the particular CA package promoted is then demonstrated scientifically, through detailed plot-based comparisons of yields, soil erosion, and runoff rates between CA and conventional farming (see for example Thierfelder and Wall, 2009) ${ }^{15}$. As in Alvord's days, quantifications of land degradation are 
used strategically to communicate urgency, and the need for revelation of 'farmer mindsets' (CA Taskforce, 2008: 5; Hobbs et al., 2008).

Invoking God and the gospel constitutes a second congruence between Alvord and CA protagonists. Just as Alvord, who built on mission-educated demonstrators and Christianised 'modern' farmers that were presumably freed of superstitious beliefs like witchcraft (Page and Page, 1991), CA is often financed and extended through churches and faith-based organisations ${ }^{16}$. For instance, Brian Oldreive's River of Life Church has been at the forefront of its promotion in Zimbabwe. Viewing CA as a way to farm 'faithfully', he equated it with 'Farming God's Way' (Oldreive, 2005). Soil cover with mulch is referred to as 'God's blanket'. The promotion of CA thus becomes an evangelizing enterprise.

A technology-driven approach, disregarding farm practice: “one size fits all”

Arguably, the most striking similarity between Alvord's model for agricultural intensification and $\mathrm{CA}$ is the disregard for the rationale of existing farm practices and for the diversity of socio-economic environments within which they take place. In Alvord's days, local practices such as shifting cultivation were perceived as wasteful and destructive, to be replaced by 'modern' integrated crop-livestock farming, modelled on northern European and American family farms (Wolmer and Scoones, 2000). Similarly, the extension of CA to smallholder farmers in southern Africa is modelled on its success in large-scale, mechanised farms in the Americas and Australia (Giller et al., 2009).

Labelling existing farm practices as wasteful and destructive is, of course, a convenient way to ignore them altogether and justify the blanket recommendation of a new set of practices. Although Alvord's understanding of African agriculture was considerable (see Alvord, 1929), he operated within the confines of the segregationist colonial state that sought 
to concentrate Africans in reserves, intensify agriculture there, while simultaneously suppressing smallholder farmers' market production. Regardless Alvord's awareness of these contradictory goals of colonial policy, his package was primarily a technological one, ignoring the embeddedness of farming practices in a wider socio-economic environment - its labour constrained production in particular.

Protagonists of CA appear to have learned little from Alvord's experiences. Again an intensification package is promoted as a 'one size fits all' set of technologies, without much attention for existing farming practices and the suitability of the promoted technologies within the socio-economic context in which they are to be adopted.

Below, in Part II, the focus shifts to understanding smallholder farming practices within their specific socio-economic environment. Understanding such practices, it is suggested, casts doubts on the suitability of CA.

\section{PART II: FARMER PRACTICE VS. INTENSIFICATION MODELS}

The material presented below builds on fieldwork among smallholder farmers in Dande Communal Area in the Zambezi Valley, a relatively thinly populated area $\left(17\right.$ pers. $\mathrm{km}^{-2}$ in 2002) in northern Zimbabwe. Here, agricultural intensification is seen as a way to spare land for wildlife conservation beyond the borders of nearby protected areas. The analysis aims to understand better the rationale of African smallholder farming, and particularly, trajectories of farm development. It is shown why Zambezi valley farmers are predisposed towards agricultural extensification.

A survey $(n=176)$ was used to construct a typology of farmer diversity in the study area, based on their practices and endowment. Four farmer types were delineated: hand-hoe farmers not growing cotton (Type 1); hand-hoe farmers growing cotton (Type 2); ploughing farmers 
growing cotton and having less than four draught animals (Type 3); and ploughing farmers growing cotton and having four draught animals or more (Type 4$)^{17}$. A sub-sample of 38 farmers representative of farmer diversity was selected for a detailed analysis of decisionmaking processes governing resource allocation to farming. First, farm labour and cash calendars were constructed. A second round of interviews focused on farmers' perspectives on 'good farming' and his/her preferences for farm development if specific inputs were increased. To facilitate dialogue on these development pathways, a role-playing game was used: the "Dande Game". The Dande Game was made of a board representing the major soil types farmers distinguish: upland loamy sand ("shapa") and upland sandy clay loam ("mutapo"), and sandy loam near rivers ("bandate"). Bottle tops were used to represent one acre plots of the five major crops cultivated in the area - cotton, maize, sorghum, cowpea and groundnut. Production assets such as labour and spans of animal draught power were represented by cards. The game was played by first asking the interviewee to represent the crop-soil type combinations of his/her farm as it was during the previous cropping season. Farmers were then asked how they would change their cropping pattern under various scenarios, such as access to all major soil types, more draught animals, or increased labour availability. During the discussions, farmers were asked to reflect on specific technologies associated with CA, that is minimum-tillage, crop residue mulching, crop rotation and intercropping with legumes. Issues discussed during these interviews were also raised in group interviews in three wards along a west-east gradient of increased population density and less tsetse infestation (see Baudron et al., 2011): from Angwa Bridge to Mazambara and Mushumbi Pools. This gradient is significant for the understanding of farm diversity as tsetse infestation prevents the use of animal drawn ploughs, while higher population densities may limit farm expansion. 


\section{Organizing production: smallholders' disposition towards agricultural extensification}

\section{Labour constrained production}

In southern Africa, farming is often limited by labour rather than land. In Zimbabwe's Zambezi Valley, available animal draught power and manpower are good predictors of farm size (Baudron et al., 2011). Hand-hoe farmers (Types 1 and 2) on average cultivate 2.1 ha, while ploughing farmers with one (Type 3) and two animal spans (Type 4) on average cultivate 3.6 and 6.0 ha, respectively.

Southern Africa is characterised by a narrow optimum planting window (Phillips et al., 1998; Raes et al., 2004), while timely first weeding is crucial to avoid problems of crop establishment (Vogel, 1994). As labour calendars evidence, smallholder farming in the Zambezi Valley, is characterised by two labour peaks; one at land preparation and planting in November-December, and one at the first weeding in January (Figure 3). For hand-hoe farmers (Type 1 and 2), who generally lack resources to hire labour, the labour peak at first weeding is particularly pronounced. Weeds grow fast and vigorously because of the relatively fertile soils and high temperatures that characterise the Zambezi Valley. For Type 1 and 2 farmers, land preparation and planting are spread over a longer time period, as field clearing and the opening of planting stations can already commence before the onset of the rains. However, weed growth is not controlled by ploughing nor are weeding efforts alleviated by the use of ox-drawn cultivators. In contrast, ploughing farmers (Type 3 and 4) face two labour peaks. These farmers can only start land preparation and planting after the onset of the rains, as ploughing requires moisture to soften the soil. Although ploughing and the use of laboursaving cultivators controls weed growth, these farmers still face a labour peak at weeding; a cultivator does not eliminate the need for manual weeding between plants in the same row (Figure 3). 
In the Zambezi Valley, the labour peak at the time of first weeding is a major determinant of the land area harvested, even for ploughing farmers. Farmers who cannot mobilise enough labour at first weeding, are forced to abandon parts of their planted field as exemplified by data from the EU-PARSEL project in the area. During the 2008-2009 season $28 \%$ of sorghum fields $(n=164)$ and $17 \%$ of cotton fields $(n=149)$ decreased by almost a third in size between planting and harvesting time.

The primacy of the labour peak at first weeding explains Zambezi Valley farmers' preference for technologies such as ploughing and residue burning that save labour at this time of the season (see below). Ploughing generally reduces weed infestation at planting time and is more effective in controlling perennial weeds than minimum-tillage (Vogel, 1994), whilst manual weeding is easier on a bare soil than on a mulched soil (see below). In opposition, technologies that increase labour demand during weeding are ill-suited to smallholders of the Zambezi Valley, particularly the resource poor. From discussions with farmers, this appears to be the case for minimum-tillage and mulching, the main components of CA (Table 1b).

Figure 3

\section{Mobilizing cash for farming}

To overcome labour constraints, farmers may purchase herbicides or hire additional labour during peak periods. In the Zambezi Valley cotton farmers receive most of their farm inputs seeds, fertilisers and pesticides - on credit from cotton companies that recover their investments in cotton. There is relatively little direct purchase of agricultural inputs. The wealthiest farmers (Type 4) spend on average only $4 \%$ of their total cash income directly on 
agricultural inputs, while for other farmer types this is $1 \%$ or less. Problems of availability, high prices and a hyper-inflationary economic environment have reduced the possibility of direct purchases of inputs in recent years. Zambezi Valley farmers who do access mineral fertilisers on credit tend to use small quantities on their cotton, as credit recovery rates are high $^{18}$. Therefore, fertile land is generally secured by investing labour in clearing an additional piece of land before the rains start (that is before labour peaks), rather than by purchasing fertiliser to maintain the fertility of already cultivated lands. This investment strategy was revealed by the Dande Game: when offered hypothetical increases in assets all farmers expanded the area of land they cultivated, instead of concentrating resources on the land already cultivated.

Farmers' peak expenditure, at planting and first weeding between November and January, reflects the investment pattern of labour hiring ${ }^{19}$. Especially farmers growing cotton on large land areas (Type 3+4) hire additional labour for weeding (Figure 4). However, during labour peaks labour availability is reduced and labour costs increase (White et al., 2005). By contrast, labour is cheap before the rainy season, as poorer hand-hoe farmers (Type 1 and 2) are keen to earn cash to purchase food. This cheap labour allows wealthier farmers to clear large tracts of fertile land for agriculture. Thus, agricultural extensification is not only driven by the high cost of fertilisers compared with the farm gate prices of agricultural commodities, making its use unprofitable, but also by the availability of cheap labour outside peak periods.

Agricultural intensification strategies that require hiring labour, particularly - as in the case of $\mathrm{CA}$ - during peak periods when labour is scarce and expensive, require substantially more cash investment. Strategies that increase cash requirements for inputs and/or for hiring labour are unlikely to be adopted when the profitability of small-scale farming remains stable or declines, as has recently been the case for cotton profitability in Zimbabwe. 


\section{Figure 4}

\section{Agricultural intensification vs. mitigating risk}

Both strategies for farmers to increase production - agricultural intensification and agricultural extensification - require more labour and/or cash inputs. But clearing new fertile lands during off-peak periods does not only require less cash than investing in fertilisers, extending one's field has other advantages as well. Farmers generally prefer to spread their labour and cash inputs to reduce the risk of crop failure.

First, in the Zambezi Valley, having a number of fields, with different soils, planted with different crops, and managed differently, is a strategy to mitigate risks of drought, pest attacks and destruction by wildlife. For instance, farmers indicated that soils richer in clay ("mutapo") are best suited for cotton. However, when exploring different cropping patterns through the Dande Game - 'what would you grow if you had access to all soil types?' - farmers indicated that in years of drought, cotton performs better on sandy loam ("bandate") ${ }^{20}$. Thus they explained their preference to spread cotton cultivation over fields with contrasting soil types given the unpredictable rainfall, rather than concentrating on one field.

Second, agricultural extensification can also serve to mitigate the effects of drought on cereal production. Farmers indicated that in dry years, those who planted a large field always harvested something: as weeds do not develop as strongly in dry years, farmers can manage large fields with less labour than during higher rainfall years. Half of the interviewed farmers indicated that during a drought year, two acres of maize weeded once would yield more than one acre of maize weeded twice. 
Crop demands, markets, livelihoods and in/extensification pathways

\begin{abstract}
As already alluded to, market prices influence farm development pathways. For instance, land scarcity and higher producer prices near urban markets may drive agricultural intensification (Bamire and Manyong, 2003; Erenstein, 2006). Equally, relative land abundance and high input prices in remote areas such as the Zambezi Valley, may predispose farmers to extensification. Woodhouse (2002) noted that these socio-economic factors may be even more important than agro-ecological conditions in explaining population growth and the orientation of farm production towards intensification or extensification.
\end{abstract}

The cash and labour demands of specific crops as well as their different uses also shape such farm development pathways. Different crops have specific meanings for people. A comparison of cotton and cereal production in the Zambezi Valley can illuminate this. Poor market prices for cereals mean that these crops are primarily grown for food although surplus production may be sold. Being independent from the market for one's food appears to be a strong social force. Even well-endowed farming households specialised in cotton production do not cease to produce cereals altogether.

Second, different crops have different labour demands. During the 'Dande Game', when asked to compare the cropped area of a farming household only growing cotton with the cropped area the same household could manage when only growing cereals, farmers highlighted the extra labour demand of cotton production for weeding and pesticide application. They estimated that a household could manage $25-60 \%$ less land area under cotton than under cereals. Accordingly, the farmers saw larger farming households - more helping hands - as more suitable for cotton cultivation, while farms with more draught animals and ploughs were considered best for cereal farming. Hence, the relative market prices for cereals and cotton may drive farm development along an intensification or an 
extensification pathway. In the Zambezi Valley extensification is probable, as the profitability of labour-demanding cotton has followed a declining trend in the past decade ${ }^{21}$, whilst cereal marketing in Zimbabwe was liberalised in 2009.

\title{
6. Farmer practice and Conservation Agriculture: an unlikely marriage
}

The above exploration of farm practices reveals how limited cash, labour peaks, low output and high input prices, and risk aversion, predispose smallholder farmers in southern Africa to agricultural extensification. The availability of - relatively fertile - land enables such an expansive farm development pathway in the Zambezi valley, but such a development is perhaps unlikely in areas characterised by high land pressure and poor soils. Nevertheless, the Zambezi Valley case illuminates why the technologies for agricultural intensification as promoted in CA are problematic in many smallholder farming contexts.

Ploughing: the hallmark of a good farmer

\begin{abstract}
Although diverse in terms of their farming practices and their endowment, interviewed farmers' responses to the questions: 'What makes a good farmer? What does (s)he have or do differently than others?' were strikingly similar: having animal draught power, a plough and a cultivator, were seen as the main attributes of a good farmer (Table 2). As for Alvord in the 1920s, the plough remains the hallmark of good farming.
\end{abstract}

Table 2 
As already shown above, Zambezi Valley farmers value the plough foremost for weed control (67\%). Secondly, in the hot and dry climate of the Zambezi Valley where yields are foremost limited by water availability, ploughing is perceived as a means to increase moisture retention (52\%) and water infiltration (45\%) (Table 3). Finally, smallholders value the plough for the rapid land preparation it permits (24\%). In low rainfall areas, the optimum planting window is narrow and the plough enables large areas of land to be cultivated quickly (Nyamudeza, 1999).

Farmer's appreciation of plough use as a way to maximise the utilization of rainwater, diametrically contradicts the view of CA protagonists, who argue that plough use should be minimised to increase water use efficiency (Gowing and Palmer, 2008; Rockström et al., 2008). Agronomists agree that on (clay-poor) loamy soils, such as those found in the Zambezi Valley, soil crusting occurs, leading to run-off and poor water infiltration. The crust can be broken by ploughing or, alternatively, its formation can be avoided by mulching as is proposed with CA (Awadhwal and Thierstein, 1985). Why then do farmers not mulch?

Table 3

\section{Mulching vs. burning crop residues}

Removing crop residues (for cattle feed) or burning them is a widespread practice among smallholder farmers in the Zambezi Valley - three quarters of the farmers interviewed did so. Hand-hoe farmers do so because retained crop residues - mulch - increase the labour burden during planting and weeding in the beginning of the season (Table 4). It may increase labour costs, as a labour hiring hand-hoe farmer explained:

\footnotetext{
"Casual workers charge you more to open planting stations in fields where you did not burn."22
} 
Such considerations are not relevant to those who plough, since ploughing incorporates most of the residues. However residue burning may also be practiced to reduce pests and weeds or to release nutrients for the crop to be planted (Table 4). During group interviews, other reasons included: facilitating mice hunting, avoiding trampling of one's field by free grazing cattle, and not attracting dangerous wildlife like elephants and buffaloes that feed on crop residues. While some reasons are specific to the Zambezi Valley, to abandon burning involves an additional labour input; for planting and weeding, as well as for constructing fire breaks as fires often spread from neighbouring fields ${ }^{23}$.

Table 4

\section{The impossibility of frequent crop rotation}

Both the Alvord and CA packages for agricultural intensification emphasise the importance of crop rotation, albeit for different reasons. For Alvord, making best use of available soil nutrients was a prime concern, and he promoted a four-year rotation with two consecutive years of maize, followed by a legume crop and a small grain crop. Consequently, half of the farm should be occupied by maize and the other half by legume and small grain crops. In CA, annual crop rotation is required as pests and diseases may be carried over to the following crop in the mulch. This means that the farm should be occupied by at least two crops on equal areas. Both types of crop rotations are highly problematic for smallholders. Firstly, not all farmers grow a wide variety of crops, or cultivate similar land areas to different crops. ${ }^{24}$

Secondly, as already mentioned above many farmers have access to different types of soils that differ in their suitability for particular crops. Farmers' preferred combinations of crops and soil types were brought out by the 'Dande Game': 1) maize on "bandate" soils 
close to the rivers, 2) sorghum and cowpea on "bandate" soils, but further away from the rivers; 3) groundnuts on lighter "shapa" soils, and; 4) cotton on "mutapo" (the heavier soils). Although limited access to specific soil types, food security and risk spreading considerations complicate such ideal-typical combinations in practice, these preferences make crop rotation impractical.

\section{'Intercropping with legumes is for poor farmers'}

Intercropping with cover crops, especially legumes, is often promoted in CA. However, in the Zambezi Valley only $20 \%$ of the interviewed farmers were practicing legume intercropping mainly groundnuts and cowpea with a cereal. The main reason given for not intercropping was crop competition, resulting in a decline in yield of the legume crop. Farmers may also associate legume intercropping with poverty:

"A good farmer is not supposed to practise intercropping; intercropping is mainly done by old people who are trying to make the most out of a small piece of land. 25

Thus, although the benefits of legume intercropping are well documented in the scientific literature (for example Craufurd, 2000), farmers in the Zambezi Valley appear committed to sole cropping as promoted in the Alvord model (Table 1a).

\section{Conclusions: Failing to yield, or failing to innovate?}

Whereas interventions in African agriculture have been aimed at agricultural intensification, the analyses presented in this article show how the socio-economic constraints faced by many smallholder farmers - that is limited cash, labour peaks, low output and high input prices, and 
high risks - predispose them towards extensification. Technical packages which may exacerbate such constraints are ill-suited to the circumstances of smallholder farmers. In the Zambezi Valley, where labour availability for weeding is a major limiting factor, the increased weed pressure in CA is a major - but probably not the only - reason preventing farmers from embracing it. Without more attractive prices for farm produce, or other sources of income, farmers will not be able to hire additional labour, or to purchase the labour-saving herbicides required to overcome the increased weed problems that may result from CA adoption.

Agricultural technologies do not, however, have strict intensifying or extensifying properties: often they have both. It is the interaction between the technology and the agroecological and socio-economic environments which directs farming on an intensification or extensification pathway. The example of the plough in Alvord's time is illustrative: although its use was promoted to intensify land use, its adoption often meant a 'diversion' towards extensification. Similarly, depending on the circumstances in which it is introduced, CA may not contribute much to agricultural intensification, but may result in agricultural expansion and extensification. For instance, the widespread adoption of CA and herbicides in the Brazilian Cerrados went hand in hand with a massive expansion of agricultural land (Landers, 2001; Klink and Macado, 2005).

As has been highlighted above, smallholder farming in the Zambezi Valley cannot be taken as representative for the southern African region as a whole, as its hot climate and relatively fertile soils render weeding rather than planting the major labour peak in production. Land abundance - enabling agricultural extensification - is, however, less specific to the Zambezi Valley than may be assumed. In areas with denser populations than the Zambezi Valley (17 pers. $\mathrm{km}^{-2}$ in 2002$)$, such as Malawi's southern province ( $>200$ pers. $\mathrm{km}^{-2}$, Benson et al. 2002), acute land shortage may indeed preclude agricultural 


\section{Acknowledgements}

This research was funded by the European Commission through the project 'Public-PrivateCommunity Partnerships to improve food security and livelihoods in South East Lowveld and Mid Zambezi Valley' and the International Research and Education Fund (INREF) of Wageningen University in the Netherlands through the 'Competing Claims on Natural Resources' research programme (http://www.competingclaims.nl). We thank Edmore 


\section{Chimimba, Edwin Chimusimbe and Knowledge Mataya for fieldwork assistance and two} anonymous referees for their critical and constructive reviews.

\section{Notes}

${ }^{1}$ Quote from: E.D. Alvord (not dated) The Gospel of the Plow or A Guided Destiny (unpublished autobiography of the Agriculturalist for Natives), National Archives of Zimbabwe (NAZ).

${ }^{2}$ The Zimbabwe Conservation Agriculture Taskforce is a collaborative effort of the FAO, ICRISAT, CIMMYT, the EU, DfID and a number of (faith-based) international donor organizations.

${ }^{3}$ www.foundationsforfarming.org (visited 23 November 2010).

${ }^{4}$ The FAO defines Conservation Agriculture as: ‘. ...resource-saving agricultural crop production that strives to achieve acceptable profits together with high and sustained production levels while concurrently conserving the environment. www.fao.org/ag/ca/1a.html (visited 23 November 2010).

5 During the 2009-2010 season, 180,000 Zambian smallholders received support to practice conservation agriculture (www.conservationagriculture.org, visited 23 November 2010), while in Zimbabwe a consortium of donors supported more than 110,000 farmers to do so (www.prpzim.info, visited 23 November 2010).

${ }^{6}$ Speech for the official opening of the Parliament of Zimbabwe in July 2010 (The Herald, 20 July 2010).

${ }^{7}$ Conservation Farming packages as promoted by ICRISAT perhaps constitute an exception as they specifically target food insecure farmers with no cattle and plough, acknowledging these farmers' need to reduce labour peaks (see Twomlow et al., 2008b).

8 Agronomists generally use "sole cropping" to refer to the practice of planting one crop in one field.. In Alvord's days this practice was known as mono-cropping, which is now often taken to mean one crop in a field continually year after year.

${ }^{9}$ The strategic use of soil erosion figures to argue for urgent action is exemplified by Whitlow (1987), who mentioned soil losses of 40 tons $^{-1}$ year $^{-1}$ in Zimbabwean Communal Areas. Disregarding the accuracy of the figure, this apparently massive figure translates to top soil loss of $2.7 \mathrm{~mm}$ per year (assuming a bulk density of top soil of $1.5 \mathrm{~g} \mathrm{~cm}^{-3}$ ). Such strategic use of soil erosion figures re-surfaces in contemporary CA promotion messages (Field Observations, Foundations for Farming Open day, River of Life Church, Harare, 1 February 2011).

${ }^{10}$ Alvord recommended 10-15 tons kraal manure per acre (37 tons per ha) every four years (Grant, 1976: 252). Manure use was also limited as it increased weed infestation (Bolding, 2003: 52), and its effectiveness depended on soil type and rainfall conditions (McGregor, 1995)

${ }^{11}$ Colony of Southern Rhodesia Statistical Bureau (1932) Official Yearbook of the Colony of Southern Rhodesia no.3, Salisbury, Government Printer. p.670. In this yearbook, average grain yield was estimated to be $700 \mathrm{~kg}$ $\mathrm{ha}^{-1}$ in 1902, and decreased to an estimated $500 \mathrm{~kg} \mathrm{ha}^{-1}$ in 1930. The number of ploughs in the Native Reserves increased exponentially, 'and by 1940 nearly every family owned one' (Scoones et al., 1996; Palmer, 1977). In that year there were about hundred agricultural demonstrators based in the Native Reserves (Davis, 1992: 53).

${ }^{12} \mathrm{http}$ ://www.foundationsforfarming.org/Groups/104832/Foundations_for_Farming/Resources/Resources.aspx (Visited 23 November 2010)

13 http://www.worldagroforestry.org/ea/?page_id=6 (Visited 23 November 2010)

14 An example is the promotional video on www.fao.org/ag/ca (visited 23 November 2010).

${ }^{15}$ Conventional' farming without fertilisers is often compared with CA with - donor supported - fertiliser (see CBDC, 2009). Thus, in these comparisons, the effect of CA per se is confounded with the effect of fertilisers. Moreover, CA adoption may be driven by NGO supported inputs more than by the merits of CA itself (Mazvimavi and Dimes (2009). Note the similarity with the valued labour input provided by Alvord's demonstrators.

${ }^{16}$ Faith-based donor organizations such as Catholic Relief Services and Care International, invest substantially in CA promotion, while FAO and other donors fund CA trainings at the River of Life church.

${ }^{17}$ The distinction between "hand-hoe" and "ploughing" is based on the mode of land preparation for the main dryland crops. Type 1 and 2 farmers never use animal draught power, while Type 3 and 4 farmers may occasionally use hand-hoes in riverbank fields or in gardens.

${ }^{18}$ Data from the EU-PARSEL project show that during the 2008-2009 season, farmers were using, on average, only $12 \mathrm{~kg} \mathrm{~N} \mathrm{ha}^{-1}, 34 \mathrm{~kg} \mathrm{P} \mathrm{ha}^{-1}$ and $6 \mathrm{~kg} \mathrm{ha}^{-1}$ on their cotton fields.

${ }^{19}$ The expenditure peak partly corresponds with the beginning of the school year, when school fees, uniforms and stationary need to be purchased. 
${ }^{20}$ Sandy clay loam has a high water retention capacity, but also a high permanent wilting point. These soils require substantial rainfall before water becomes available for the crop. Sandy loam has less capacity to retain moisture and a lower permanent wilting point.

${ }^{21} \mathrm{~A}$ farmer explained ' $250 \mathrm{~kg}$ could buy one head of cattle in the 1990s; nowadays, twice this amount is required' (Interview with Mr R. Matongora, Madzeverete, 9 November 2009)

${ }^{22}$ Interview with Courage Nhamoyemari (2 February 2010).

${ }^{23}$ Fires may spread from neighbouring farms or natural vegetation, that are annually burnt for a number of reasons, for example to facilitate hunting of antelopes.

${ }^{24}$ For instance, in the Zambezi Valley in 2006, hand-hoe farmers were growing an average of 1.1 ha of cereals and an average of 0.7 ha of cotton $(n=78)$, whilst ploughing farmers were growing an average of 1.3 ha of cereals and an average of 2.6 ha of cotton $(n=98)$.

${ }^{25}$ Interview with Rambros Matongora (9 November 2009)

${ }^{26}$ Population figures of 2008, United Nations Population Division (http://esa.un.org/UNPP/, visited 23 November 2010)

${ }^{27}$ Deforestation rates for the period 2000-2005, data from the Global Forest Resource Assessment of 2005 (http://foris.fao.org/static/data/fra2005/global_tables/FRA_2005_Global_Tables_EN.xls, visited 23 November 2010) 


\section{Bibliography}

Allan, W. (1965) The African Husbandman. (London: Oliver and Boyd).

Alvord, E.D. (1929) Agricultural life of Rhodesian natives. Native Affairs Department Annual, 7, pp. 9-16.

Andersson, J.A. (1999) The Politics of land scarcity: land dispute in Save Communal Area, Zimbabwe. Journal of Southern African Studies, 25(4), pp. 553-578.

Andersson, J.A. (2007) How much did property rights matter? Understanding food insecurity in Zimbabwe: A critique of Richardson. African Affairs, 106(425), pp. 681-690.

Awadhawal, N.K. and Thierstein, G.E. (1985) Soil crust and its impact on crop establishment: a review. Soil and Tillage Research, 5(3), pp. 289-302.

Bamire, A.S. and Manyong, V.M. (2003) Profitability of intensification technologies among smallholder maize farmers in the forest-savanna transition zone of Nigeria. Agriculture, Ecosystems and Environment, 100, pp. 111-118.

Baudron, F., Corbeels, M., Andersson, J.A., Sibanda, M. and Giller, K.E. (2011) Delineating the drivers of waning wildlife habitat: the predominance of cotton farming on the fringe of protected areas in the Zambezi Valley, Zimbabwe. Biological Conservation. doi: 10.1016/j.biocon.2011.01.017

Bolding, J.A. (2003) Alvord and the demonstration concept: Origins and consequences of the agricultural demonstration scheme, 1920-1944, in: J.A. Bolding, J. Mutimba and P. van der Zaag (eds), Interventions in Smallholder Agriculture: Implications for Extension in Zimbabwe, (Harare: University of Zimbabwe Publications), pp. 35-83. 
Bolding, A. (2004) In hot water. A study on sociotechnical intervention models and practices of water use in smallholder agriculture, Nyanyadzi catchment, Zimbabwe. Doctoral dissertation, Wageningen University, The Netherlands.

Boserup, E. (1965). The Conditions of Agricultural Growth: The Economics of Agrarian Change under Population Pressure. (London: George Allen and Urwin).

Campbell, B.M., Bradley, P. and Carter, E. (1997) Sustainability and peasant farming systems: observations from Zimbabwe. Agriculture and Human Values, 14, pp. 159-168.

CBDC-Community Biodiversity Development and Conservation Programme (2009) Conservation Agriculture: A Sustainable Farming Manual, (Harare: Community Technology Development Trust).

Chambers, R. and Ghildyal, B. P. (1985) Agricultural research for resource-poor farmers: The farmer-first-and-last model. Agricultural Administration, 20(1), pp. 1-30.

Chimhowu, A. and Woodhouse, P. (2008) Communal tenure and rural poverty: land transactions in Svosve Communla Area, Zimbabwe. Development and Change, 39(2), pp. 285-308.

Craufurd, P.Q. (2000) Effect of plant density on the yield of sorghum-cowpea and pearl millet-cowpea intercrops in Northern Nigeria. Experimental Agriculture, 36, pp. 379-395.

Davis, A.G. (1992) The work of E.D. Alvord in the Mazowe Valley. Zambezia, XIX(1), pp. 47-63.

Djurfeldt, G., Holmén, H., Jirström, M. and Larsson, R. (2005) The African Food Crisis: Lessons from the Asian Green Revolution. (Wallingford UK: CABI). 
Erenstein, O. (2006) Intensification or extensification? Factors affecting technology use in peri-urban lowlands along an agro-ecological gradient in West Africa. Agricultural Systems, 90, pp. 132-158.

Frost, P., Campbell, B., Luckert, M.M., Mutamba, M. and Mandondo, A. (2007) In search of improved livelihoods in semi-arid regions through local management of local resources: lessons from case studies in Zimbabwe. World Development, 35, pp. 1961-1974.

Giller, K.E., Cadish, G. and Palm, C. (2002) The North-South divide! Organic wastes, or resources for nutrient management? Agronomie, 22, pp. 703-709.

Giller, K.E., Rowe, E.C., de Ridder, N. and van Keulen, H. (2006) Resource use dynamics and interactions in the tropics: scaling up in space and time. Agricultural Systems, 88, pp. 8-27.

Giller, K.E., Witter, E., Corbeels, M. and Tittonell, P. (2009) Conservation agriculture and smallholder farming in Africa: the heretics' view. Field Crops Research, 114, pp. 23-34.

Grant, P.M. (1976), Peasant farming on infertile sands. Rhodesia Science News 10(10), pp. 252-254.

Gowing, J.W. and Palmer, M. (2008) Sustainable agricultural development in sub-Saharan Africa: the case for a paradigm shift in land husbandry. Soil Use and Management, 24, pp. 92-99.

Government of Southern Rhodesia (1952) Annual report of the Secretary of Native Affairs, Chief Native Commissioner, and director of Native Development for the year 1951. (Salisbury: Government Printer).

Hobbs, P.R., Sayre, K. and Gupta, R. (2008) The role of conservation agriculture in sustainable agriculture. Philosophical transactions of the Royal Society, 363, pp. 543-555. 
Huang, J., Pray, C. and Rozelle, S. (2002) Enhancing the crops to feed the poor. Nature, 418, pp. 678-684.

Ikpe, F.N., Powell, J.M., Isirimah, N.O., Wahua, T.A.T. and Ngodigha, E.M. (1999) Effects of primary tillage and soil amendment practices on pearl millet yield and nutrient uptake in the Sahel of West Africa. Experimental Agriculture, 35, pp. 437-448.

Kassam, A., Friedrich, T., Shaxson, F. and Pretty, P. (2009) The spread of conservation agriculture: justification, sustainability and uptake. International Journal of Agricultural Sustainability, 7(4), pp. 292-320.

Klink, C.A., Machado, B. (2005) Conservation of the Brazilian Cerrado. Conservation Biology, 19(3), pp. 707-713.

Landers, J.N. (20001) How and why the Brazilian zero tillage explosion occurred, in: Stott, D.E., Mohtar, R.H., Steinhardr, G.C. (Eds) (2001) Sustaining the Global Farm. Selected Papers from the 10th International Soil Conservation Organization Meeting, Purdue University, USA, 24-29 May 1999.

Larson, B.A. and Frisvold, G.B. (1996) Fertilizers to support agricultural development in subSaharan Africa: what is needed and why. Food Policy, 6, pp. 509-525.

Machingaidze, V.E.M. (1991) Agrarian change from above: the Southern Rhodesia Native Land Husbandry Act and African response. The International Journal of African Historical Studies, 24, pp. 557-588.

MACO - Ministry of Agriculture and Co-operatives (2004) National Agricultural Policy 2004-2015. (Lusaka: Republic of Zambia).

Mazvimavi, K. and Dimes, J. (2009) Trends in Conservation Farming Adoption and Impacts Bulawayo: ICRISAT (Presentation for the CA Task Force meeting, 10 July 2009) 
Mazvimavi, K. and Twomlow, S. (2009) Socioeconomic and institutional factors influencing adoption of conservation farming by vulnerable households in Zimbabwe. Agricultural Systems, 101, pp. 20-29.

McGregor, J. (1995) Conservation, control and ecological change : the politics and ecology of colonial conservation in Shurugwi, Zimbabwe. Environment and History, 1, pp. 257-279.

Nyamudeza, P. (1999) Agronomic Practices for the Low-rainfall Regions of Zimbabwe, in E. Manzungu, A. Senzanje and P. van der Zaag (Eds.) Water for Agriculture in Zimbabwe: Policy and Management Options for the Smallholder Sector. (Harare: University of Zimbabwe Publications), pp. 49-63.

Oldreive, B. (2005) The strategic importance of "Farming God's Way" in poverty relief. (Harare: Farming God's Way, River of Life).

Page, S.L.J. and Page, H.E. (1991) Western hegemony over African agriculture in Southern Rhodesia and its continuing threat to food security in independent Zimbabwe. Agriculture and Human Values, Fall 1991, pp. 3-18.

Palmer, R. (1977). Land and Racial Domination in Rhodesia. (London: Heinemann)

Phillips, J.G., Cane, M.A. and Rosenzweig, C. (1998) ENSO, seasonal rainfall patterns and simulated maize yield variability in Zimbabwe. Agricultural and Forest Meteorology, 90, pp. 39-50.

Phimister, I. (1986) Discourse and the discipline of historical context: conservationism and ideas about development in Southern Rhodesia 1930-1950. Journal of Southern African Studies, 12, pp. 263-275.

Phimister, I. (1988) An Economic and Social History of Zimbabwe: Capital Accumulation and Class Struggle (London: Longman). 
Phimister, I. (1993) Rethinking the reserves: Southern Rhodesia's Land Husbandry Act reviewed. Journal of Southern African Studies, 2, pp. 225-239.

Raes, D., Sithole, A., Makarau, A. and Milford, J. (2004) Evaluation of early planting dates recommended by criteria currently used in Zimbabwe. Agricultural and Forest Meteorology, 125, pp. 177-185

Rockström, J., Kaumbutho, P., Mwalley, J., Nzabi, A.W., Temesgen, M., Mawenya, L., Barron, J., Mutua, J. and Damgaard-Larsen, S. (2008) Conservation farming strategies in East and Southern Africa: yields and rain water productivity from on-farm action research. Soil \& Tillage Research, 103, pp. 23-32.

Scoones, I. (1996) Hazards and Opportunities. Farming Livelihoods in Drylands Africa: Lessons from Zimbabwe. (London: Zed Books).

Scoones, I. (1997) Landscapes, fields and soils: understanding the history of soil fertility management in Southern Zimbabwe. Journal of Southern African Studies, 23, pp. 615634.

Stocking, M.A. (1978) Relationship of agricultural history and settlement to severe soil erosion in Rhodesia. Zambezia, VI (ii), pp. 129-145.

Thierfelder, C. and Wall, P.C. (2009) Effects of conservation agriculture techniques on infiltration and soil water content in Zambia and Zimbabwe. Soil \& Tillage Research, 105, pp. 217-227.

Twomlow, S., Urolov, J.V., Jenrich, M. and Oldreive, B. (2008a) Lessons from the field Zimbabwe's Conservation Agriculture Task Force. Journal of SAT Agricultural Research, 6.

Twomlow, S., Hove, L., Mupangwa, W., Masikati, P. and Mashingaidze, N. (2008b) Precision conservation agriculture for vulnerable farmers in low potential zones. 
Proceedings of the Workshop on Increasing the Productivity and Sustainability of Rainfed Cropping Systems of Poor, Smallholder Farmers, Tamale, Ghana, 22-25 September 2008.

Vogel, H. (1994) Weeds in single-crop conservation farming in Zimbabwe. Soil \& Tillage Research, 31, pp.169-185.

White, D.S., Labarta, R.A. and Leguía, E.J. (2005) Technology adoption by resource-poor farmers: considering the implications of peak-season labor cost. Agricultural Systems, 85, pp. 183-201.

Whitlow, R. (1987) A national soil erosion survey for Zimbabwe. Journal of Soil and Water Conservation, 42, pp. 239-242.

Wolmer, W. and Scoones, I. (2000) The science of "civilized agriculture": the mixed farming discourse in Zimbabwe. African Affairs, 99, pp. 575-600.

Woodhouse, P. (2002) Natural Resource Management and Chronic Poverty in Sub-Saharan Africa: an Overview Paper. CPRC Working Paper 14. Institute for Development, Policy and Management, University of Manchester, United Kingdom.

World Bank (2008) World Development Report 2008. (Washington D.C.: Agriculture for Development).

Zimbabwe Conservation Agriculture Task Force (2009) Farming for the Future, a Guide to Conservation Agriculture in Zimbabwe. (Harare: Zimbabwe).

Zingore, S., Murwira, H.K., Delve, R.J. and Giller, K.E. (2007) Influence of nutrient management strategies on variability of soil fertility, crop yields and nutrient balances on smallholder farms in Zimbabwe. Agriculture Ecosystem and Environment, 119, pp. 112126. 
Figure 1 - Three pathways to increase production: Extensification, Green Revolution (increased use of external inputs) and Ecological intensification (improved resource-use efficiency). Downward arrows represent water and nutrient losses. Sizes of the various arrows are proportional to the corresponding fluxes. Impact of the three pathways on yield (i.e. harvest per surface area) and quantity of input used per surface area is described by ' $\cong$ ', meaning the value remains roughly constant; ' $>$ ', meaning the value increases; and ' $>$ ', meaning the value increases greatly.

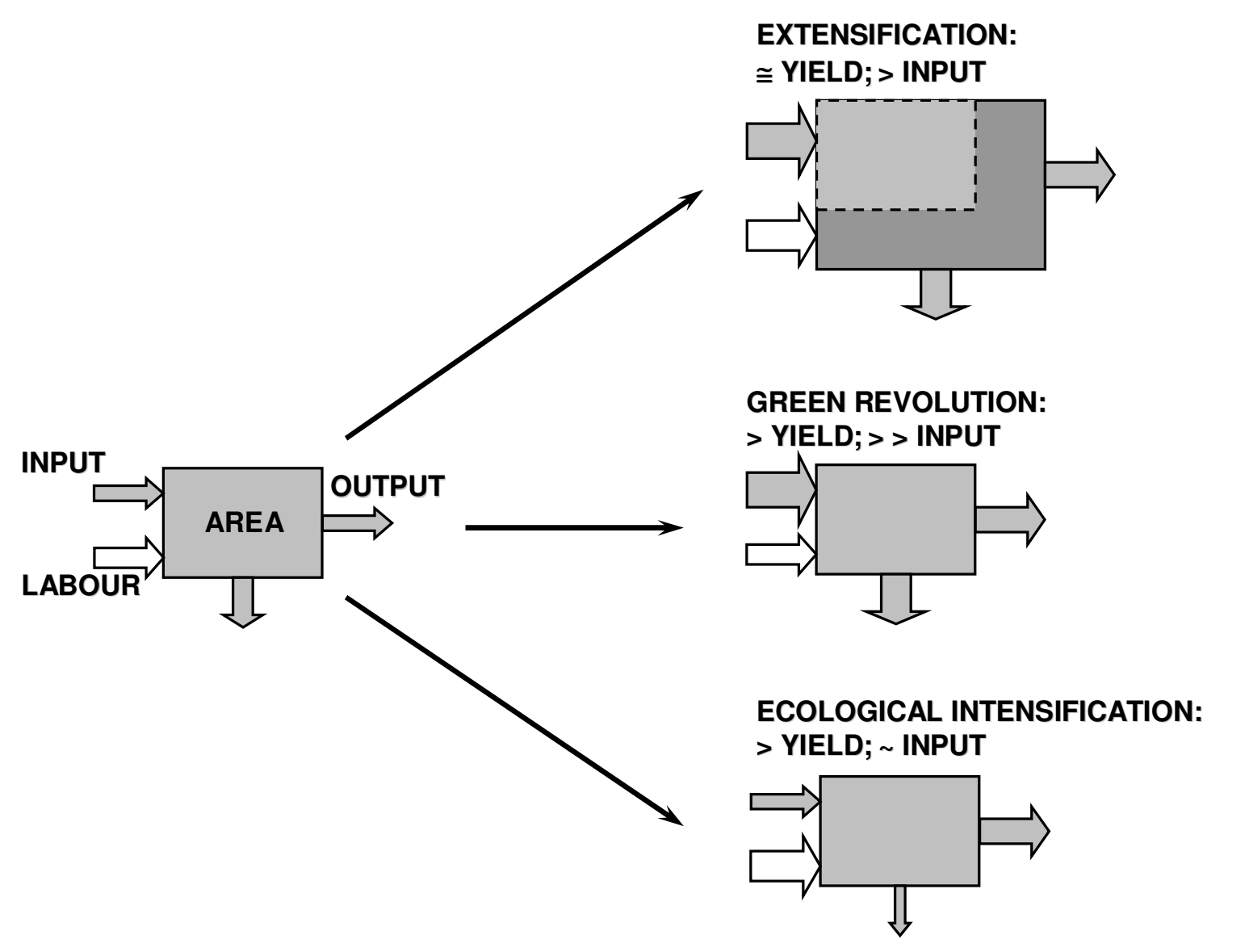


Figure 2 - Two main principles of $\mathrm{CA}$ and their consequences: possible negative effects on production and implications for farming practices.

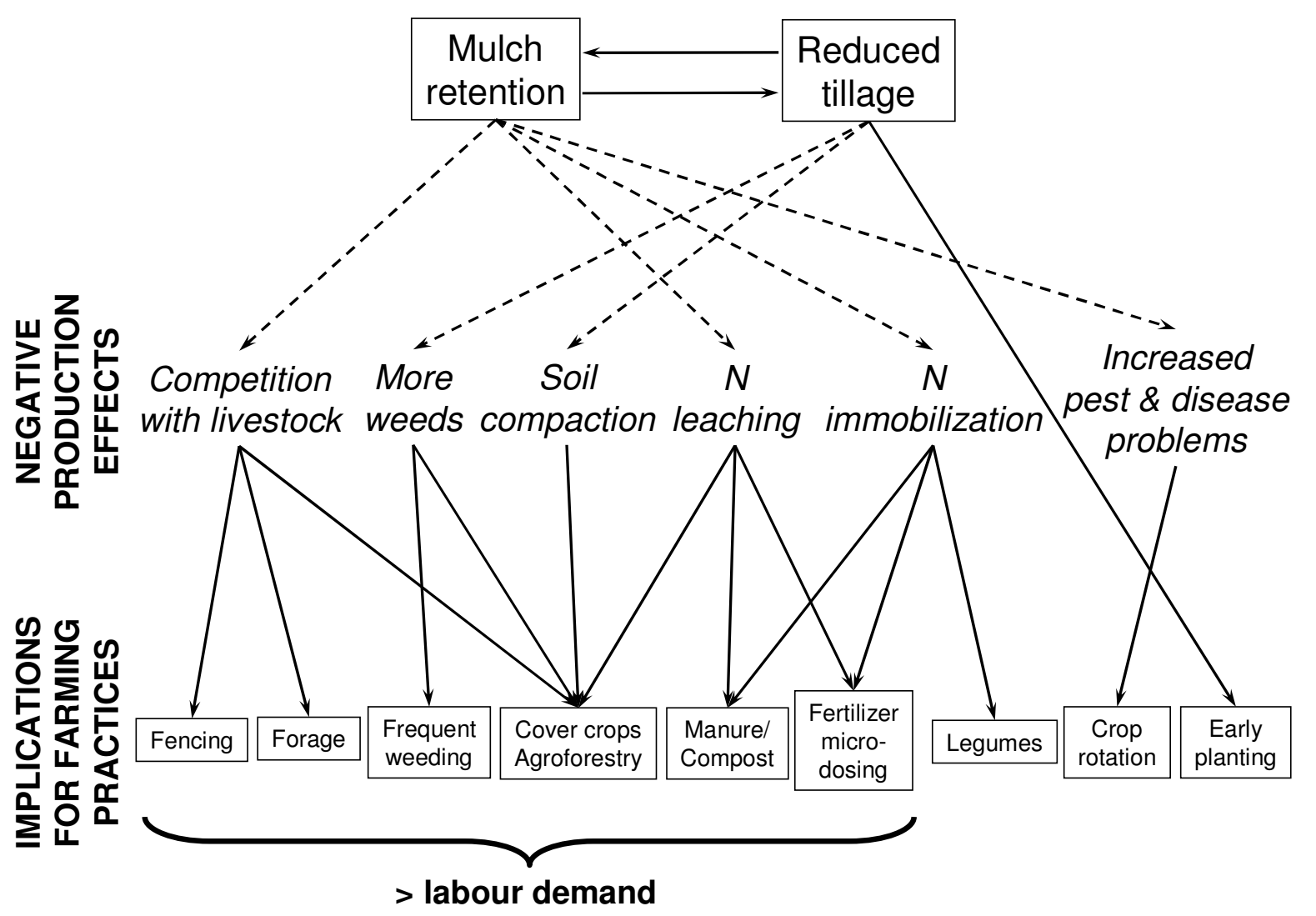


Figure 3 - Mean monthly labour allocation for three types of farmers during the 200708 season in Dande Communal Land, Zimbabwe $(n=38)$.

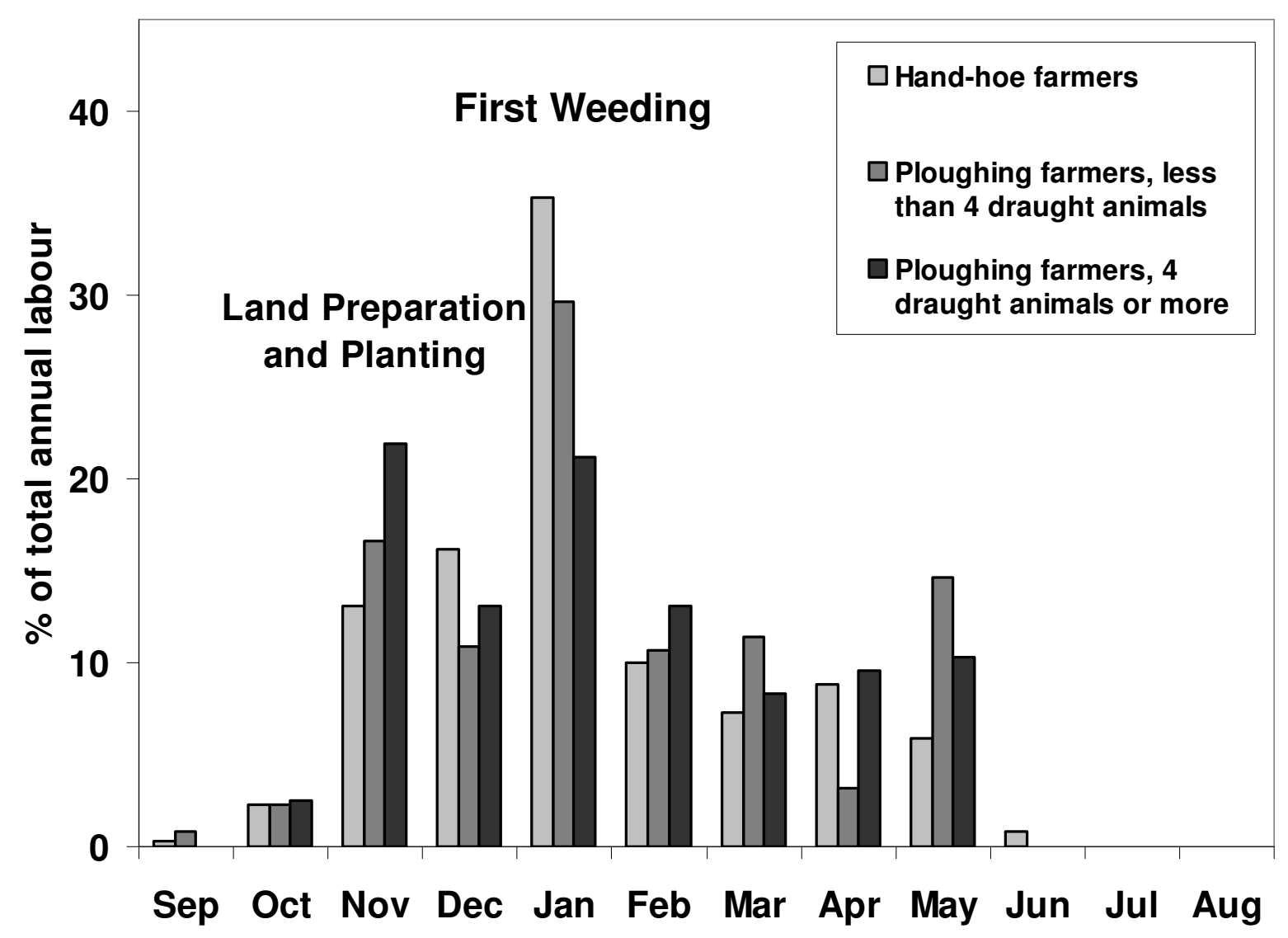


Figure 4 - Mean monthly cash allocation for three types of farmers during the season 2007-08 in Dande Communal Land, Zimbabwe $(n=38)$. Cash expenditure during the period November-January represent labour hiring and, to a lesser extent, expenses related to schooling. Cash expenditures in the period May-July represent the purchase of clothes, productive assets such as livestock and other household needs using cotton income.
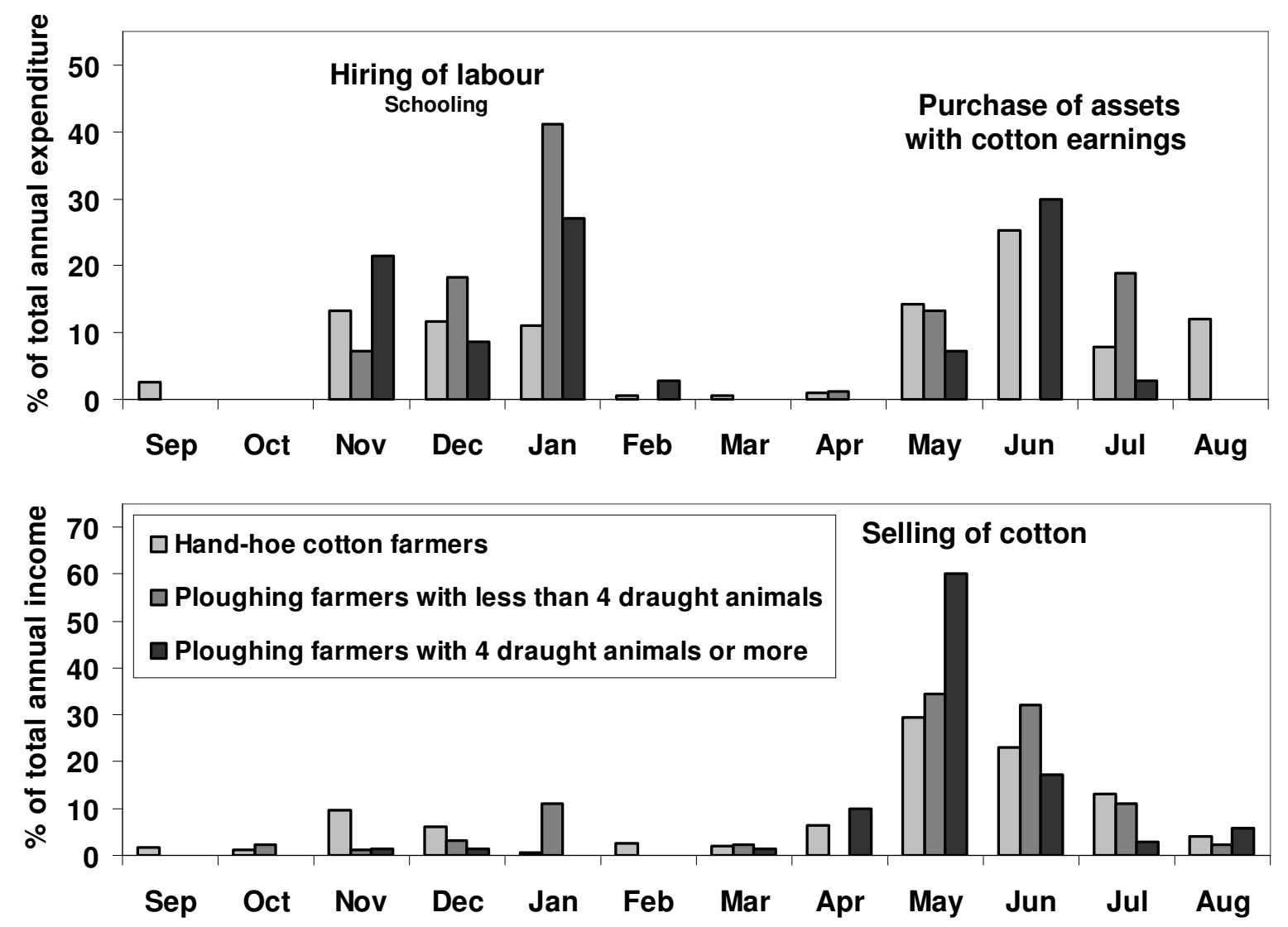
Table 1 - Components of a) the Alvord model and b) Conservation Agriculture and their impact on yield and labour needs $(+/ 0 /-$ indicate positive, neutral and negative impacts, respectively; arrows indicate implications)

a)

Components
$\begin{aligned} & \text { Ploughing } \\ & \text { Manuring }\end{aligned}$
Sole-cropping/tree removal
Planting in lines/cultivating ${ }^{(7)}<$

b)

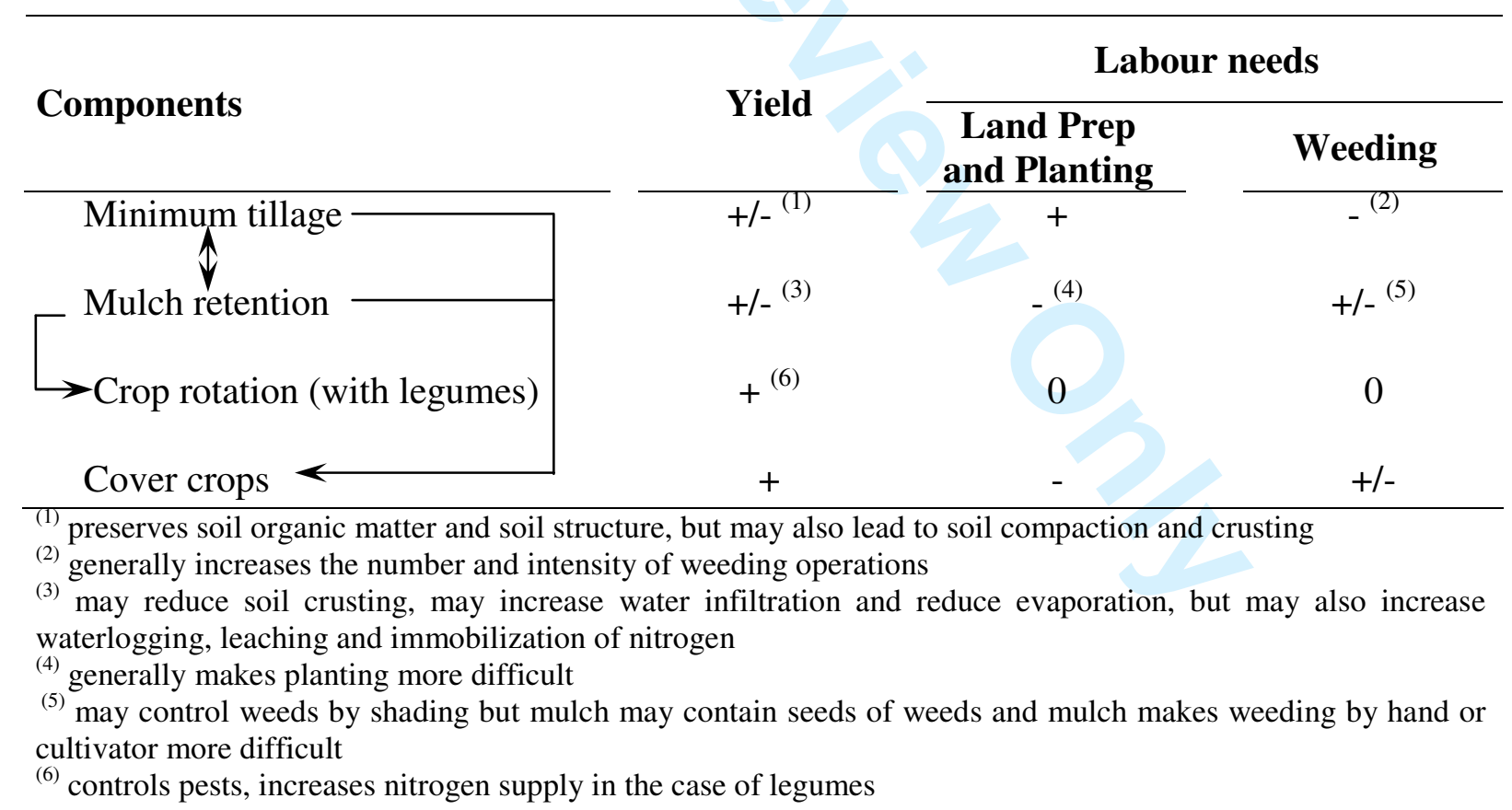


Table 2 - 'What makes a good farmer (murimi akanaka)? What does (s)he have or do differently than others?' $(n=36)$

\begin{tabular}{lrrrr}
\hline What makes a good farmer? & & $\begin{array}{r}\text { Number of } \\
\text { respondents }\end{array}$ & & $\begin{array}{r}\text { Proportion of } \\
\text { respondents }\end{array}$ \\
\cline { 1 - 1 } $\begin{array}{l}\text { Having animal draught power, } \\
\text { plough(s) and cultivator(s) }\end{array}$ & 35 & & $97 \%$ \\
$\begin{array}{l}\text { Producing surpluses } \\
\begin{array}{l}\text { Having seeds (quantity and } \\
\text { quality) }\end{array}\end{array}$ & 17 & & $47 \%$ \\
$\begin{array}{l}\text { Having manpower (family } \\
\text { and/or hired labour) }\end{array}$ & 13 & & $36 \%$ \\
$\begin{array}{l}\text { Having a large field } \\
\text { Practicing proper weeding }\end{array}$ & 12 & & $33 \%$ \\
$\begin{array}{l}\text { Using chemicals (fertilizers, } \\
\text { pesticides, etc) }\end{array}$ & 9 & & $25 \%$ \\
\hline
\end{tabular}


Table 3 - "What are the benefits of ploughing?" $(n=34)$

\begin{tabular}{|c|c|c|}
\hline Reasons for ploughing & $\begin{array}{l}\text { Number of } \\
\text { respondents }\end{array}$ & $\begin{array}{r}\text { Proportion of } \\
\text { respondents }\end{array}$ \\
\hline Weed control & 22 & $67 \%$ \\
\hline Increased moisture retention & 17 & $52 \%$ \\
\hline Improved water infiltration & 15 & $45 \%$ \\
\hline $\begin{array}{l}\text { Fast and easy plant growth due } \\
\text { to loosened soil }\end{array}$ & 17 & $52 \%$ \\
\hline Fast land preparation / big land & 8 & $24 \%$ \\
\hline
\end{tabular}


Table 4 - "Why do you burn residues?" (n=26)

\begin{tabular}{|c|c|c|}
\hline Reasons for burning & $\begin{array}{l}\text { Number of } \\
\text { respondents }\end{array}$ & $\begin{array}{r}\text { Proportion of } \\
\text { respondents }\end{array}$ \\
\hline $\begin{array}{l}\text { Easier land preparation and } \\
\text { weeding }\end{array}$ & 18 & $72 \%$ \\
\hline $\begin{array}{l}\text { Reduction in termite and } \\
\text { millipede populations }\end{array}$ & 6 & $24 \%$ \\
\hline Weed control & 5 & $20 \%$ \\
\hline Increased fertility & 4 & $16 \%$ \\
\hline
\end{tabular}

